\title{
Does Industry Specialist Auditor Provide More Insights in Their audit report? An Empirical Study of Key Audit Matters Section
}

\author{
Li-Jen $\mathrm{He}^{1}$
}

\begin{abstract}
In 2015, International Auditing and Assurance Standards Board (IAASB) released new International Standards on Auditing 701 and required auditors to disclose key audit matters (KAM) in the audit report. Similar standards were also released in the United States in 2017 and the United Kingdom and Ireland Financial Reporting Council (FRC) in 2014. As KAM are expected to inform on matters of the greatest significance during an audit, before exploring the question regarding whether investors will obtain useful information from additional matter disclosures, the anterior consideration may be in regard to how audit quality affects the disclosure quality of KAM. This study use hand-collected data of the KAM disclosed in the audit reports of Taiwanese listed companies in 2016 to explore the association between auditor industry specialization and audit quality by the disclosure of KAM in new audit reports. The empirical results show that the association between the industrial specialist audit partner and the measurement of KAM quality is significantly positively related. The findings support our hypothesis that specialist auditors' KAM are more informative than those issued by non-specialist auditors, and provide new evidence supporting prior studies about the superior auditing ability and disclosure quality of auditor industry specialist.
\end{abstract}

Keywords: Key Audit Matters, KAM, International Standards on Auditing 701, International Auditing and Assurance Standards Board.

${ }^{1}$ Department of Accounting, National Yunlin University of Science and Technology, Taiwan.

Article Info: Received: June 10, 2021. Revised: July 6, 2021.

Published online: July 11, 2021. 


\section{Introduction}

In order to enhance the transparency of company audit report, auditing standard development authorities around the world have proposed or approved standards that significantly improved the auditor's reporting process and quality. The International Auditing and Assurance Standards Board (IAASB) released new International Standards on Auditing 701 (hereafter referred to as ISA701) in January 2015 and required auditors to disclose key audit matters (KAM) in the audit report. Similar standards were also released by Public Company Accounting Oversight Board (PCAOB) of the United States in 2017 and the United Kingdom and Ireland Financial Reporting Council (FRC) in 2014. In compliance with international development in auditing, Taiwan Accounting Research and Development Foundation (ARDF) released the Statements of Auditing Standards No. 58 "Communicating Key Audit Matters in the Independent Auditor's Report" (hereafter referred to as SAS No. 58), requiring auditors to communicate key matters in an audit and contain these matters in the audit reports.

KAM involve regions of an audit that require a significant amount of professional judgment for appropriate evaluation or that pose the most difficulty in obtaining and evaluating evidence (PCAOB, 2013). The changes in auditing standards may have a significant impact on the assessment of auditor's liability (Gimbar, Hansen, and Ozlanski, 2016) and audit practice (Vanstraelen, Schelleman, Meuwissen, and Hofmann 2012), which are generally considered as of the main influencing factors of audit quality in past studies.

Prior studies have discussed the possible effect of additional disclosures in an auditor's report on audit quality (Gutierrez, Minutti-Meza, Tatum, and Vulcheva, 2018; Vanstraelen et al., 2012). From the perspective of an auditor's reputation, the additional disclosure requirements of KAM in new audit reports would lead to an increase in transparency of audit practices (Vanstraelen et al., 2012) and might place companies and auditors under more careful scrutiny by users (Gutierrez et al., 2018). On the other hand, from the litigation perspective, prior studies have suggested that the additional disclosure requirements of KAM in the new audit reports may affect the auditors' legal responsibility (Backof, Bowlin, and Goodson, 2017; Brasel, Doxey, Grenier, and Reffett, 2016; Gimbar et al., 2016).

Since 2017, PCAOB $^{2}$ required that the critical audit matters (CAMs) must be included in an auditor report, which is a discussion of matters related to accounts or disclosures that are material to financial statements and involve especially challenging, subjective, or complex auditor judgment. Prior studies provide mixed results regarding the incremental informativeness of KAM (e.g., Boolaky and Quick, 2016; Lennox, Schmidt, and Thompson, 2015; Christensen, Glover, and Wolfe, 2014), we argue these result maybe due to the audit quality is not good enough to

2 The PCAOB audit reporting initiative refers to these matters as critical audit matters (CAMs) and the IAASB ISA and Taiwan ARDF as key audit matters (KAMs). For ease of exposition, we elect to use the term KAMs throughout this study unless specifically referring to that of PCAOB. 
"insight" the KAM and then not able to provide incremental information to users. As KAM are expected to inform on matters of the greatest significance during an audit, before exploring the question regarding whether investors will obtain useful information from additional matter disclosures, the anterior consideration may be in regard to how audit quality affects the disclosure quality of KAM. This question is important for standard setters and the research community because KAM can hardly increase its informativeness for investors unless the information quality revealed by KAM is fine.

In combine of audit quality and the auditing standards related to KAM disclosure, the two factors that mainly affect the quality of its disclosure should be the ability of auditors to identify KAM that are material to the financial statements and involve especially challenging, subjective, or complex auditor judgments and the capacity and independence of auditors to properly disclose these issues. Industry specialist auditors, according to experience or reputation aspects, are demonstrated to process better capability and higher independence (Liu, Xie, Chang, and Forgione, 2017; Rose-Green, Huang, and Lee, 2011; Reichelt and Wang, 2010; Chin and Chi, 2009; Gul et al., 2009; Lim and Tan, 2010; Payne, 2008; Romanus et al., 2008; Krishnan, 2003; Schauer, 2002). ${ }^{3}$ Since industry specialist auditors are considered to possess higher audit quality, the purpose of this study is to explore whether auditor industry specialization, and indicator of audit quality, can communicates more important KAM in their audit reports. In other word, we expect when specialist auditor's can provide important KAM in their report, the KAM then can be more informative to the users. The results of our study can make up for the gap in the literature that why KAM was not demonstrated to be informative, is because of auditor did not possess of certain industry specialty to identify KAM.

To address this question, this study use hand-collected data of the KAM disclosed in the audit reports of Taiwanese listed companies in 2016 to explore the association between auditor industry specialization and audit quality by applying the disclosure quality of KAM in new audit reports. Moreover, this study develops a comprehensive indicator based on companies' KAM disclosure content according to Chen (2017) including following six criteria indexes: (1) whether the matter discussed should be considered as a KAM; (2) whether the discussion of KAM provided linkage to a specific level of the account it mentioned; (3) whether excessive standardized phraseology is used to discuss KAM; (4) whether the content of KAM provides the index of KAM-related disclosure in financial reports; (5) whether the title of KAM is appropriate; and (6) whether the note of KAM is adequate. and propose that KAM disclosed by industry specialist auditors will possess higher scores (fewer deficiencies) of the comprehensive indicators.

The empirical results show that the association between the industrial specialist

3 Earlier studies have addressed auditor industry specialization issues using audit firm size settings and assumed better industry knowledge and experience for large audit firms (e.g., Becker, DeFond, Jiambalvo, and Subramanyam, 1998; Francis et al., 1999; Reynolds and Francis, 2000). 
audit partner indicator variable and the measurement of KAM content quality is significantly positive for both logistic regression and the ordinal logit regression. The findings support our hypothesis that compared with the content quality of KAM in an audit report that discussed by non-specialist auditors, the content quality of KAM is higher in the audit report that discussed by specialist auditors; and provide new evidence supporting prior studies about the superior auditing ability and disclosure quality of auditor industry specialist. Besides, the empirical results of considering the effect of auditor change reveal that the positive association between the industrial specialist audit partner indicator variable and KAM content quality is significant only for companies that did not change their auditors for current year, which suggests that auditors' client specific knowledge may affect the quality of KAMs disclosure. Moreover, the additional test reviews that the impact of auditor industry specialization on the content quality of KAM is more pronounced for correctly identifying KAM issues, avoiding to use excessive standardized phraseology to discuss KAM, and adequately make the note of KAM.

This study is expected to make the following contributions. Regarding the limitation of data, rare empirical evidence exists about the disclosure of KAM until now; further, this study will use hand-collected data from KAM in Taiwan to provide empirical evidence regarding the consequence of the revolution in audit reporting. This is our first contribution. Furthermore, while Lennox et al. (2015) (i.e., the only published empirical evidence prior to this study, to our best knowledge) provide evidence of the response of users of audit reports, this study is expected to provide evidence of the response of audit report providers for the new audit standard, and this is our contribution, i.e., our second contribution. Finally, while industry specialist auditors typically demonstrate higher audit quality, no evidence associated with the new audit report has been provided to date. This study will provide evidence of the impact of auditor industry specialization on audit quality under the new audit regulation region (this is our third contribution).

The remainder of this paper is organized as follows. The next section presents the institutional background and develops our hypotheses. The third section presents the research method used to test these hypotheses. We present the experimental results in the fourth section, followed by our analysis of the impact of auditor industry specialization on KAM' disclosure quality in the discussion section. The last section presents our conclusions.

\section{Background and Hypotheses Development}

\subsection{Changes of the auditor report considered by the PCAOB, IAASB, and Taiwan ARDF}

To provide more valuable information and increase the information transparency of an audit, countries and economies around the world seek to enhance the form and content of an audit report to make it more relevant and informative for financial statement users.

The PCAOB and the IAASB have proposed significant changes to the audit 
reporting model and introduced new audit-reporting initiatives that incorporate important changes to an auditor's report for the financial statement audit. The standards proposed by the PCAOB $(2013 \mathrm{a}, 2013 \mathrm{~b})^{4}$ and issued by the IAASB (2015a, 2015b) require the auditor to make additional disclosures to close the information gap; that is, the gap between the information that users desire and the information available through the audited financial statements, other corporate disclosures, and the auditor's report. One of the most important changes is the requirement of disclosure of significant audit matters.

In addition to this new requirement regarding significant audit matters, which are critical audit matters (CAMs) under the PCAOB audit reporting initiative and key audit matters (KAM) under ISA 700, the primary difference between the PCAOB (CAMs) and IAASB (KAM) is that, whereas CAMs include all significant matters that are documented in the engagement completion document, reviewed by the engagement quality reviewer, or communicated to the audit committee, KAM are selected from matters communicated with those charged with governance ( $\mathrm{Be}^{\prime}$ dard et al., 2016). In order to comply with international trends and enhance the transparency of audit reports, ARDF in Taiwan revised SAS No. 58 in 2015 and required auditors to communicate significant matters that used the term KAM as IAASB in the audit and contained these matters in the audit reports as well. For the recognition of significant audit matters, the CAMs of AACSB and the KAM of IAASB and ARDF discuss aspects of the audit that required a significant amount of professional judgment to evaluate appropriately or that presented the most difficulty in obtaining and evaluating evidence.

ARDF in Taiwan released SAS No. 58 "Communicating Key Audit Matters in the Independent Auditor's Report" (hereafter referred to as SAS No. 58) on April 12, 2016, which required auditors to communicate the key matters in the audit and that contained these matters in the audit reports. This statement applies to the audits of general purpose financial statements of listed companies, specifically related to circumstances during which the auditor otherwise decides to communicate key audit matters in the auditor's report.

Under SAS No. 58, the auditors shall communicate with company governance and determine matters that required significant auditor attention while performing an audit. KAM can be seen as audit regions that require significant judgment by the auditor when performing an audit or that pose the most difficulty in obtaining audit evidence and are expected to have a higher risk of material misstatement. In addition, the description of each KAM shall include a reference to discuss the identified

4 PCAOB had proposed the standard "Proposed Auditing Standard on the Auditor's Report on an Audit of Financial Statements when the Auditor Expresses an Unqualified Opinion" in 2013 and reproposed this standard in 2016, which would supersede portions of AS 3101 "Reports on Audited Financial Statements" and related amendments to PCAOB standards. On June 1, 2017, the PCAOB adopted the new auditing standard and related amendments require auditors to include in the auditor's report a discussion of the critical audit matters (CAMs). The standard "Communication of CAMs for audits of large accelerated filers" will be effective for audits for fiscal years ending on or after June 30, 2019. 
matters and include explanations as to why the matters were considered appropriate for disclosure. As a result, after the adoption of SAS No. 58, users of audit reports are expected to obtain more information about auditors' apprehension when performing an audit through the information of KAM in addition to the audit opinions themselves.

The disclosed KAM can be seen as another window of the audit report that provides users weith a clearer view of the audit work and important issues of a company's financial statements. However, while the new audit report displays a new way of communicating and can be linked to a wider range of emerging external reports to include both financial and nonfinancial information, the identification and confirmation of KAM also provide other challenges for auditors.

\subsection{Impacts of KAM Disclosure}

KAM are expected to enhance the communicative value of an auditor's report; however, owing to the novelty, evidence of the impact of KAM is rare (Sirois, Bédard, and Bera, 2018). Because KAM are expected to serve as a tool to improve communication between financial statement users and auditors, prior studies have mainly focused on the two most effected group of KAM, i.e., financial statement users (Christensen, Glover, and Wolfe, 2014; Simnett and Huggins, 2014; Boolaky and Quick, 2016; Lennox, Schmidt, and Thompson, 2015; Boolaky and Quick, 2016; Sirois et al., 2018) and auditors (e.g., Backof, Bowlin, and Goodson, 2017; Brasel, Doxey, Grenier, and Reffett, 2016; Gimbar, Hansen, and Ozlanski, 2016).

By analyzing numerous recent academic papers related to these newly proposed or issued standards around the world, Bédard, Coram, Espahbodi, and Mock (2016) suggested that KAM may improve information flow to users in regard to the entity and the audit but also that there may be important unintended consequences to consider, such as the impact on the auditor's decision to report aggressive accounting estimates to the audit committee and on management's willingness to share information with the auditor about accounting choices. Due to the limitation of data, most studies process the influence of disclosing KAM using the experimental method. Christensen et al. (2014) examined how nonprofessional investors react to an audit report's KAM paragraph, which is centered on the audit of fair value estimates, and found that experimental participants who receive a KAM paragraph are more likely to change their investment decisions. The authors suggested that, among nonprofessional investors, communication of critical audit matters in an audit report is influential. In contrast, the results of Boolaky and Quick (2016), who conducted an experiment involving a sample of 105 bank directors to determine the predictors of bank director perceptions and decisions, revealed that KAM does not affect the perceptions and decisions of bank directors. Sirois et al. (2018) extended studies by improving previous experimental research on KAM by providing participants with a complete set of financial statements, which is more representative of the information environment in which users actually operate. By exploring whether and how the addition of mandatory paragraphs that highlight 
KAM in an auditor's report affects users' information acquisition process using eyetracking technology, Sirois et al. (2018) revealed that KAM possess an attentiondirecting impact, in that participants access KAM-related disclosures more rapidly and pay relatively more attention to them when KAM are communicated in an auditor's report. The only published empirical evidence, to our knowledge, about the information content of KAM is provided by Lennox et al. (2015) who explored the market reaction to auditors' risks of material misstatement (which are denoted as RMMs in their study) disclosure in the audit reports of $488 \mathrm{UK}$ companies that are subject to the new audit reporting standard. By processing both short- and longwindow market reactions to measure investors' responses to the new risk disclosures, the researchers revealed that investors do not find these disclosures incrementally informative. Overall, prior studies provide mixed evidence regarding whether investors will obtain useful information from KAM disclosures.

While prior studies have provided diverse results of the incremental informativeness of KAM, this study cogitates that the increased information value of KAM should be varied by the variance of audit quality. Because KAM are required to communicate regarding matters that, in the auditor's professional judgment, are of the greatest significance in the audit of financial statements of the current period, the ability of auditors to identify KAM that are actually substantial and the capacity and independence of auditors to properly disclose them are the anterior question that should be considered, as KAM can hardly increase its informativeness for investors unless the information quality revealed by KAM is adequate.

\subsection{Impacts of auditor industry specialization on KAM disclosure}

Industry specialist auditors typically demonstrate superior competence and higher independence for their industry (or client), along with specific knowledge and reputation (Liu, Xie, Chang, and Forgione, 2017; Rose-Green, Huang, and Lee, 2011; Reichelt and Wang, 2010; Chin and Chi, 2009; Gul et al., 2009; Lim and Tan, 2010; Payne, 2008; Romanus et al., 2008; Behn, Choi, and Kang, 2008; Krishnan, 2003; Schauer, 2002; Emby, C. and M. Favere-Marchesi. 2010).

For disclosure quality, Rose-Green, Huang, and Lee (2011) examined the association between auditor industry specialization and the disclosure of internal control weaknesses (ICWs) by firms that filed first-time Section 404 reports with the Securities and Exchange Commission (SEC). Using univariate and logistic regression analyses, the authors revealed that firms audited by industry specialist auditors are more likely to report ICWs than firms audited by non-specialist auditors. In addition, by exploring the association among auditor differentiation, mitigating management actions, and audit-reporting accuracy for distressed firms, Bruynseels, Knechel, and Willekens (2011) demonstrated that, compared with non-specialists, specialist auditors are more likely to issue a going-concern opinion for soon-to-be bankrupt companies when management undertakes strategic turnaround initiatives. For the effects of industry specialization on audit quality for new clients, Liu, Xie, Chang, and Forgione (2017) also addressed that, while there is a decline in audit 
quality for non-industry specialists, industry specialists are more likely to maintain audit quality for new clients.

However, while industry specialist auditors are demonstrated to possess higher audit quality, no evidence associated with the new audit report has been provided to date. For the disclosure of KAM, to identify KAM that are substantial and are involved in especially challenging, subjective, or complex auditor judgment and, further, to properly disclose these matters should depend on both the competence and the independence of auditors suggested by DeAngelo (1981). From the perspective of auditors' competence of detecting and communicating KAM, the acquisition of client-specific knowledge of industry specialist auditors can result in higher audit quality (Geiger and Raghunandan, 2002; Johnson et al., 2002; Myers et al., 2003; Mansi, Maxwell, and Miller, 2004; Ghosh and Moon, 2005), and from the perspective of auditors' independence, higher reputation cost of industry specialist auditor may embolden them to frankly and exclusively describe the KAM they would like to communicate with financial statement users.

\subsection{Content quality of KAM disclosure}

Similar to the FRC, to prevent auditors from issuing identical audit reports according to reference examples, the Taiwan ARDF does not provide the model or format for KAM disclosure of new audit reports. While this decision is in accordance with the objective of new auditing standards, to provide more clientspecific information in the "entity specific audit report," it also exposes auditors to the wide variety of KAM disclosures. By examining the content of KAM disclosed in audit reports for Taiwan listed companies in 2016, the first year that required a new type of audit report, Chen (2017) addressed that a number of KAM disclosures demonstrate presentation or substantial deficiencies, which may cause financial statement users to have difficulty to read or to understand KAM information.

The possible reasons for the deficiencies of KAM disclosures can be divided into two aspects. One of them is that, because it is the first year (and the first time) that the new type of audit report has been implemented, auditors with insufficient experience or without powerful knowledge and intellectual integration supporting a team may not be able to fully and accurately state the KAM they found in the audit report due to capacity limitations, i.e., the key check items and the corresponding check procedures. Another is that auditors have enough experience and knowledge to fully and accurately disclose or communicate the KAM in the audit report, but, for strategic purposes, they choose to more indistinctly discuss the KAM they found in the check report. From the viewpoint of auditor competence and independence, industry specialist auditors who possess more industry- and client-specific auditing experience and have higher reputation cost should be more likely to integrally describe and discuss the KAM they found in their audit reports. Accordingly, this study considers that KAM disclosed in audit reports prepared by industry specialist auditors are more likely to contain all substances required to be disclosed by the TSAS No. 58 and have fewer deficiencies; thus, the second hypothesis is proposed 
as follows:

Hypothesis: Compared with the content quality of KAM in an audit report that discussed by non-specialist auditors, the content quality of KAM is higher in the audit report that discussed by specialist auditors.

\section{Research Method}

For the content of KAM, Chen (2017) revealed that presentation or substantial deficiencies of KAM disclosure may cause financial statement users to have difficulty to read or understand the information of KAM. Thus, this study develops a comprehensive index, according to Chen (2017), to capture the integrity degree of a company's KAM disclosure content, which include following six criteria: (1) whether the matter discussed should be considered as a KAM; (2) whether the discussion of KAM provided linkage to a specific level of the account it mentioned; (3) whether excessive standardized phraseology is used to discuss KAM; (4) whether the content of KAM provides the index of KAM-related disclosure in financial reports; (5) whether the title of KAM is appropriate; and (6) whether the note of KAM is adequate.

For each company, this study will identify the deficiencies according to the abovementioned issue, if any, and each deficiency will be deducted one point off the comprehensive index. That is, companies without any deficiency will receive a seven off the index, and companies with whole deficiencies, as mentioned above, will receive a zero off the index.

\subsection{Measures of auditor industry specialization}

According to prior studies (e.g., Balsam et al. 2003; Carcello and Nagy 2004; Krishnan 2003; Cenker and Nagy 2008; Romanus et al. 2008; Chin and Chi 2009; Mascarenhas, Cahan, and Naiker 2010), we will use an audit partner's market share as a proxy for the audit partner's industry specialization. Furthermore, among definitions of market share, we will use their client's sales to measure the market share of audit partners since it has been used most often in prior studies 5 .

Since the audit reports of public companies in Taiwan must disclose the names of audit partners, we can measure the specialization of both a specific audit partner.

5 Although most prior studies have used market share as a proxy for an audit firm's or auditor's specialization, they have based the use on different definitions of market share such as clients' sales, clients' assets, clients numbers, audit fee and so on. 
We measure the specialization of an audit partner $(i)$ in a specific industry $(k)$ year as:

$$
\text { SPECIALIZA TION }_{i k}=\frac{\sum_{j=1}^{J_{i k}} S A L E_{i j k}}{\sum_{j=1}^{J_{i k}} \sum_{i=1}^{I_{k}} S A L E_{i j k}}
$$

where SALE denotes clients' sales revenue, and the numerator is the sum of sales of all the audit partner $i$ 's clients $(j)$ in industry $k$. The denominator in equation (1) is the total sales of industry $\mathrm{k}$. Then we identify the audit parts that have largest two market share ${ }^{6}$ in an industry as specialist audit partners and construct an indicator variable that equals one if the audit partner of a company is an industry specialist, and zero otherwise.

Moreover, while the requirement for dual signatures ${ }^{7}$ in Taiwan raises a measurement issue concerning the identification of individual specialists, we believe that the specialist of any single audit partner can be share to the entire audit team.

\subsection{Empirical Model}

To examine the hypothesis, this study provides following regression to test the association between auditor industry specialization and disclosure quality of KAM:

$$
\begin{gathered}
K A M D Q=\alpha_{1}+\beta_{1} S P E+\beta_{2} B I G N+\beta_{3} C P A T E N+\beta_{4} C P A E X P+\beta_{5} S I Z E+\beta_{6} C G \\
+\beta_{7} C O M P L E X+\beta_{8} M B+\beta_{9} L O S S+\beta_{10} L E V+\text { IndustryDummies }+\varepsilon
\end{gathered}
$$

Where: $\mathrm{KAMDQ}=$ quality of $\mathrm{KAM}$ disclosure, which measured by a comprehensive index that captures the degree of the KAM disclosure content over a company for Hypothesis (the detailed measurement method is discussed below).

$\mathrm{SPE}=$ an indicator variable of industry specialist auditor which denote to 1 for a company that audited by an industry specialist auditor, and 0 otherwise;

$\mathrm{BIGN}=$ an indicator variable of $\mathrm{Big} \mathrm{N}$ which denote to 1 for a company that audited by a Big $\mathrm{N}$ firm, and 0 otherwise;

CPATEN=audit tenure of the audit partners which is measure by the longer

6 In our main analyses, we use the largest market share to identify the industry specialist according to Chi and Chin (2009) who explore the influence of auditor industry specialization of accounting restatement in Taiwan. Besides, since prior studies have used arbitrary market share percentages, such as $10 \%, 15 \%$, or 30\%, to denote auditor industry expertise (Craswell et al. 1995; Ferguson and Stokes 2002; Cenker and Nagy 2008), we will consider other proper cutoff point for the specialist distribution for sensitive analyses.

7 In Taiwan, public companies are required to engage two audit partners to audit their financial reports and both auditors have to sign for the audit reports. 
continuous audit years for a company between audit partners;

CPAEXP=listed companies audit experience of the audit partners which is measure by the longer continuous audit years for a company between audit partners;

$\mathrm{SIZE}=$ natural logarithm of the book value of total assets at year-end;

$\mathrm{CG}=\mathrm{a}$ corporate governance index that captures the degree of the corporate governance circumstances over a company. The index is constructed based on 6 corporate governance provisions, including board size, board share-holdings ratio, the percentage of shares pledged to board members, the ratio of independent directors and supervisors, the ratio of family-controlled directors and supervisors, and institutional holdings ratio, where a high $\mathrm{CG}$ index indicates stronger governance. Thus, we code firms 1 (for strong governance) if the appointing firm's $\mathrm{CG}$ index is beyond the sample median, and 0 otherwise.

COMPLEX=the operational complexity of audit clients, which measured by the ratio of accounts receivable and inventory to total assets

$\mathrm{MB}=$ market to book ratio.

LOSS=indicator variable that denote to 1 for companies with negative income before extraordinary items;

LEV=long-term debt divided by total assets.

Industry Dummies=Dummy variables for the industries of sample companies.

The main variable this study interest in is $S P E$, the indicator variable of industry specialist auditors; further, this study expects $\beta_{l}$ to be significant positive, which establishes the hypotheses that, compared with the KAM of non-specialist auditors, the KAM disclosed by specialist auditors have higher quality. Besides the indicator variable of industry specialist auditors, this study includes audit firm size $(B I G N)$, audit tenure (CPATEN), and audit experience(CPAEXP) to control the impact of audit quality on auditors' opinions according to prior studies (e.g., Craswell, Stokes, and Laughton 2002). The following corporation and governance characteristics are used as control variables, as they have been found to be associated with audit quality and reporting (e.g., Francis and Krishnan, 2001; Geiger and Raghunandan, 2002; DeFond et al., 2002; Carey and Simnett, 2006; Lim and Tan, 2010; Robinson, 2008; Sultana et al., 2015). ${ }^{8}$

Because corporate governance is suggested to be one of major mechanisms that influence the relationship among a board of directors, management, and audit firms, it can extend to the issuance of an audit report. Therefore, this study includes a corporate governance index $(C G)$ that captures the degree of corporate governance circumstances over that of a company. Besides, while poor profitability, high leverage, and more growth-centric companies are perceived as being of higher risk due to more aggressive opportunistic behavior of corporate management and may

8 Since prior studies of audit opinion mainly focused on the issuing of a going-concern opinion, the influential factors of financial distress are mainly considered in their regressions. For the reason that the focus of this study is on the type of KAM rather than the going-concern opinion, this study will not include all variables suggested by prior studies. 
influence auditors' consideration of the audit opinion, this study includes an indicator denoting companies with negative income (LOSS), leverage $(L E V)$, and growth opportunities $(M B)$ in the regression as well. Besides, with regard to the control of audit risks, the operation complexity of client companies may affect the types of auditor opinions as well (Wu et al. 2011), and the operating complexity (COMPLEX) of client companies is included according to prior studies (Francis et al. 2005; Choi et al. 2010; Zerni 2011). At last, client size (SIZE) is included, while prior studies suggest there is a size effect on stock returns for an audit opinion, and it may influence an auditor's decision on opinions.

\subsection{Sample Selection}

Since SAS No. 58 required listed companies in Taiwan begin to include the communication of KAMs in their audit opinions for annual reports in 2016, this study uses Taiwanese listed companies in 2016 to be the empirical sample. KAMs will be hand collected from the annual reports that published on the Taiwan Market Observation Post System. This study will process following steps to identify the account mentioned in KAMs. First, we down load the annual reports of 2016 for each company and read the KAMs information. Second, we read the content of each audit report and to identify if their have certain kind of insufficiency. Third, we gave each company their score of KAM disclosure (which fewer insufficiency means higher scores), and they were followed by a double check of another researcher. If two researchers had different viewpoint of a certain disclosure, the disagreement(s) would be discussed to the other researcher to get the third opinion. In other words, KAM of each company were read and evaluated by at least two researchers, and some of them may be read and evaluated by three. Therefore, we believe that the evaluation of KAM disclosure of this study is creditable and convinced. Data of other variables are obtained from Taiwan Economic Journal (TEJ) Database.

For sampling, we utilize a sample of Taiwan listed companies with available data in TEJ of year 2016. We first delete TDR companies and companies in financial institutions since they have different company characteristics and audit requirement from other industries in the nature. Following, we eliminate observations that do not have sufficient KAM, auditor, or required financial data. After applying the above criteria, we obtain a total sample with 1,558 companies. The sample selection process is presented in Panel A of Table 1. Panel B of Table 1 shows the industry distribution of sample companies. Panel B of reveals that the KAM disclosure scores of industries fall between 3 and 4 on average. The highest score is 4 points for the chemical industry, and the lowest is 3 points for wire industry. The result suggests that in the first year of KAM disclosure requirements, there is still room for improvement as a whole. 
Table 1: Sample Selection

\begin{tabular}{|c|c|c|c|c|c|c|c|c|c|}
\hline \multicolumn{10}{|c|}{ Panel A: Sample Selection } \\
\hline \multicolumn{6}{|c|}{ Total listed companies on TWSE in 2016} & \multicolumn{4}{|c|}{1,713} \\
\hline \multicolumn{6}{|c|}{ Less: financial institutions and TDR companies } & \multicolumn{4}{|c|}{$(61)$} \\
\hline \multicolumn{6}{|c|}{ Less: Companies without sufficient data } & \multicolumn{4}{|c|}{$(98)$} \\
\hline \multicolumn{6}{|c|}{ Final Sample } & \multicolumn{4}{|c|}{1,554} \\
\hline \multicolumn{10}{|c|}{ Panel B: Sample Distributions } \\
\hline \multirow[b]{2}{*}{ Industry } & \multirow[b]{2}{*}{\begin{tabular}{|} 
Number of \\
sample \\
companies \\
\end{tabular}} & \multirow[b]{2}{*}{$\%$} & \multicolumn{6}{|c|}{\begin{tabular}{|l|} 
Average Scores of each KAM \\
\end{tabular}} & \multirow{2}{*}{$\begin{array}{c}\text { Average KAM } \\
\text { score } \\
\text { of each } \\
\text { company }\end{array}$} \\
\hline & & & KAM1 & KAM2 & KAM3 & KAM4 & KAM5 & KAM6 & \\
\hline Cement & 7 & 0.45 & 0.57 & 0.29 & 1.00 & 0.86 & 0.57 & 0.71 & 4.00 \\
\hline Foods & 28 & 1.80 & 0.43 & 0.46 & 0.93 & 0.96 & 0.50 & 0.29 & 3.57 \\
\hline Plastics & 27 & 1.73 & 0.15 & 0.26 & 0.85 & 0.96 & 0.44 & 0.48 & 3.15 \\
\hline Textiles & 55 & 3.53 & 0.24 & 0.20 & 0.89 & 0.87 & 0.60 & 0.40 & 3.20 \\
\hline Mechanical electronics & 93 & 5.97 & 0.37 & 0.40 & 0.89 & 0.90 & 0.43 & 0.48 & 3.47 \\
\hline Wire & 16 & 1.03 & 0.38 & 0.31 & 0.88 & 1.00 & 0.31 & 0.13 & 3.00 \\
\hline $\begin{array}{c}\text { Chemical \& } \\
\text { Biotechnology }\end{array}$ & 145 & 0.06 & 0.41 & 0.31 & 0.92 & 0.92 & 0.48 & 0.48 & 3.57 \\
\hline Glass & 5 & 0.32 & 0.40 & 0.00 & 1.00 & 1.00 & 0.40 & 0.40 & 3.20 \\
\hline Paper & 7 & 0.45 & 0.29 & 0.29 & 0.86 & 1.00 & 0.71 & 0.29 & 3.43 \\
\hline Iron \& steel & 44 & 2.82 & 0.30 & 0.45 & 0.91 & 0.98 & 0.59 & 0.45 & 3.68 \\
\hline Rubber & 13 & 0.83 & 0.38 & 0.62 & 0.77 & 0.85 & 0.69 & 0.54 & 3.85 \\
\hline Automobile & 7 & 0.45 & 0.43 & 0.14 & 0.71 & 1.00 & 0.57 & 0.29 & 3.14 \\
\hline Electronics & 798 & 0.35 & 0.33 & 0.90 & 0.93 & 0.34 & 0.34 & 3.36 & 0.06 \\
\hline Construction & 73 & 4.69 & 0.47 & 0.37 & 0.89 & 0.99 & 0.60 & 0.26 & 3.58 \\
\hline Transportation & 27 & 1.73 & 0.59 & 0.26 & 0.93 & 0.93 & 0.44 & 0.33 & 3.48 \\
\hline Tourism & 36 & 2.31 & 0.50 & 0.56 & 0.89 & 0.89 & 0.64 & 0.33 & 3.81 \\
\hline Department stores & 31 & 1.99 & 0.48 & 0.52 & 0.90 & 0.94 & 0.52 & 0.29 & 3.65 \\
\hline Other & 142 & 9.37 & 0.06 & 0.40 & 0.47 & 0.89 & 0.90 & 0.17 & 0.17 \\
\hline Total & 1554 & 00.00 & 0.37 & 0.38 & 0.90 & 0.94 & 0.50 & 0.35 & 3.38 \\
\hline
\end{tabular}




\section{Empirical Results}

\subsection{Descriptive Statistics}

Table 2 presents the descriptive statistics and difference test of sample companies. Panel A of Table 2 shows that the mean of HQKAM is 0.438 , which represents that about $44 \%$ of sample companies are classified to have higher Content quality of KAM disclosure. In addition, the mean of KAM is 3.376 reveals that, on average, sample companies get only about $60 \%(3.376 / 6)$ of the total KAM disclosure scores that we used to evaluate; and it exposes that in the first year of KAM disclosure requirements, a lot of auditors may not "ready" for providing adequate KAMs in their audit reports. The mean of the indicator variable of industry specialist audit partner $(S P E)$ and big $\mathrm{N}$ audit firms $(B I G N)$ is 0.05 and 0.878 , respectively; which show that about $5 \%$ of sample companies are audited by industrial specialist audit partners, and nearly $90 \%$ of sample companies are audited by big $\mathrm{N}$ audit firms. Panel $\mathrm{B}$ of Table 2 presents the difference test of companies with high KAM disclosure scores $(H Q K A M)$ and low KAM disclosure scores $(L Q K A M)$ which are divided by the median of the KAM disclosure scores of sample companies, and companies with higher KAM disclosure scores are considered to have better content quality of KAM disclosure in their audit reports. One can see that, the median of the indicator variable of industry specialist audit partner (SPE) in companies with higher KAM disclosure scores is significant higher than that in companies with lower KAM disclosure scores, which preliminary suggests that the quality of KAM communicated by industry specialist audit partners is higher than that of non-specialist ones. In addition, Panel B of Table 2 also shows that the complexity of operations, growth opportunities, and leverage of audit clients are also significantly different between companies with high and low KAM disclosure scores, which advocates that the content quality of KAM disclosure of audits will be different among companies with different operation and business risks.

Table 3 shows the Spearman correlation between variables. From the table, one can see that the indicator variable of industry specialist audit partner (SPE) is significantly positively associated with both the indicator of higher quality KAM disclosure (HQKAM) and the original score of KAM disclosure $(K A M)$, which suggests that industrial audit partners are likely to have higher content quality of KAM disclosure. That is, from Table 3, the positive association between the industry specialist audit partner and KAM disclosure quality is supported by these preliminary results. 
Table 2: Descriptive and Difference Test

\begin{tabular}{|l|c|c|c|c|c|c|c|c|c|c|c|}
\hline \multicolumn{7}{|c|}{ Panel A: Descriptive Statistics (N=1554) } & \multicolumn{3}{|c|}{ Panel B: Mann-Whitney Test } \\
\hline & & & Std. & & & & & & $\begin{array}{c}\text { HQKAM } \\
\text { (N=681) }\end{array}$ & $\begin{array}{c}\text { LQKAM } \\
\text { (N=873) }\end{array}$ & $\begin{array}{c}\text { M-W } \\
\text { statistic }\end{array}$ \\
\hline Variables & Mean & Median & Dev. & Min & $\mathbf{2 5 \%}$ & $\mathbf{5 0 \%}$ & $\mathbf{7 5 \%}$ & Max & Median & Median & \\
\hline HQKAM & 0.438 & 0.000 & 0.496 & 0.000 & 0.000 & 0.000 & 1.000 & 1.000 & & & \\
\hline KAM & 3.376 & 3.000 & 1.080 & 0.000 & 3.000 & 3.000 & 4.000 & 6.000 & 4.000 & 3.000 & $35.196^{* * *}$ \\
\hline SPE & 0.050 & 0.000 & 0.218 & 0.000 & 0.000 & 0.000 & 0.000 & 1.000 & 0.001 & 0.000 & $2.064 * *$ \\
\hline BIGN & 0.878 & 1.000 & 0.328 & 0.000 & 1.000 & 1.000 & 1.000 & 1.000 & 1.000 & 1.000 & $-1.831^{*}$ \\
\hline CPATEN & 4.443 & 5.000 & 1.843 & 1.000 & 3.000 & 5.000 & 6.000 & 8.000 & 5.000 & 4.000 & -0.291 \\
\hline CPAEXP & 16.221 & 17.000 & 4.834 & 4.000 & 13.000 & 17.000 & 19.000 & 27.000 & 17.000 & 16.000 & 0.255 \\
\hline SIZE & 6.657 & 6.572 & 0.619 & 5.427 & 6.226 & 6.572 & 6.999 & 8.587 & 6.582 & 6.564 & -0.163 \\
\hline CG & 3.708 & 4.000 & 1.086 & 0.000 & 3.000 & 4.000 & 4.000 & 7.000 & 4.000 & 4.000 & 1.239 \\
\hline COMPLEX & 30.777 & 29.541 & 18.289 & 0.370 & 17.401 & 29.541 & 41.865 & 84.635 & 28.047 & 30.367 & $-2.877 * * *$ \\
\hline MB & 1.741 & 1.320 & 1.391 & 0.460 & 0.880 & 1.320 & 2.053 & 8.830 & 1.370 & 1.270 & $2.288^{* *}$ \\
\hline LOSS & 0.218 & 0.000 & 0.413 & 0.000 & 0.000 & 0.000 & 0.000 & 1.000 & 0.000 & 0.000 & -0.564 \\
\hline LEV & 40.451 & 39.790 & 18.051 & 5.000 & 26.453 & 39.790 & 53.290 & 82.850 & 38.230 & 41.180 & $-2.671^{* * *}$ \\
\hline
\end{tabular}

The definition of variables are as follows. KAMDQ is quality of KAM disclosure, which measured by a comprehensive index that captures the degree of the KAM disclosure content over a company for Hypothesis (the detailed measurement method is discussed below). SPE is an indicator variable of industry specialist auditor which denote to 1 for a company that audited by an industry specialist auditor, and 0 otherwise. BIGN is an indicator variable of Big $\mathrm{N}$ which denote to 1 for a company that audited by a Big $\mathrm{N}$ firm, and 0 otherwise. CPATEN is audit tenure of the audit partners which is measure by the longer continuous audit years for a company between audit partners. CPAEXP is listed companies audit experience of the audit partners which is measure by the longer continuous audit years for a company between audit partners. SIZE is natural logarithm of the book value of total assets at year-end. CG is a corporate governance index that captures the degree of the corporate governance circumstances over a company. The index is constructed based on 6 corporate governance provisions, including board size, board share-holdings ratio, the percentage of shares pledged to board members, the ratio of independent directors and supervisors, the ratio of familycontrolled directors and supervisors, and institutional holdings ratio, where a high CG index indicates stronger governance. Thus, we code firms 1 (for strong governance) if the appointing firm's CG index is beyond the sample median, and 0 otherwise. COMPLEX is the operational complexity of audit clients, which measured by the ratio of accounts receivable and inventory to total assets. $\mathrm{MB}$ is market to book ratio. LOSS is indicator variable that denote to 1 for companies with negative income before extraordinary items. LEV is long-term debt divided by total assets. 
Table 3: Spearman Correlations

\begin{tabular}{|c|c|c|c|c|c|c|c|c|c|c|c|c|}
\hline & HQKAM & KAM & SPE & BIGN & CPATEN & CPAEXP & SIZE & $\mathbf{C G}$ & COMPLEX & MB & LOSS & LEV \\
\hline HQKAM & 1.000 & & & & & & & & & & & \\
\hline KAM & $0.893^{* * *}$ & 1.000 & & & & & & & & & & \\
\hline SPE & $0.052^{* *}$ & $0.071^{* * *}$ & 1.000 & & & & & & & & & \\
\hline BIGN & $-0.046^{*}$ & $-0.046^{*}$ & $0.059^{* *}$ & 1.000 & & & & & & & & \\
\hline CPATEN & -0.007 & -0.026 & -0.020 & $0.118^{* * *}$ & 1.000 & & & & & & & \\
\hline CPAEXP & 0.006 & -0.009 & $0.089^{* * * *}$ & 0.032 & $0.105^{* * *}$ & 1.000 & & & & & & \\
\hline SIZE & -0.004 & -0.010 & $0.220^{* * * *}$ & $0.106^{* * *}$ & $0.084^{* * *}$ & $0.128^{* * * *}$ & 1.000 & & & & & \\
\hline CG & 0.031 & 0.024 & 0.022 & $0.106^{* * *}$ & $0.048^{*}$ & -0.013 & $-0.044^{*}$ & 1.000 & & & & \\
\hline COMPLEX & $-0.073^{* * *}$ & $-0.081^{* * *}$ & 0.000 & -0.029 & 0.031 & -0.007 & $0.046^{*}$ & 0.001 & 1.000 & & & \\
\hline MB & $0.058^{* *}$ & $0.066^{* * *}$ & 0.030 & $0.052^{* *}$ & $-0.059^{* *}$ & -0.020 & $-0.191^{* * *}$ & $0.216^{* * *}$ & $-0.084^{* * *}$ & 1.000 & & \\
\hline LOSS & -0.014 & -0.013 & -0.036 & $-0.060^{* *}$ & $-0.044^{*}$ & -0.038 & $-0.215^{* * *}$ & $-0.102^{* * *}$ & $-0.202^{* * *}$ & $-0.107^{* * *}$ & 1.000 & \\
\hline LEV & $-0.068^{* * *}$ & $-0.087^{* * *}$ & $0.094^{* * *}$ & -0.032 & -0.025 & 0.023 & $0.337^{* * *}$ & $-0.093^{* * *}$ & $0.302^{* * *}$ & $-0.058^{* *}$ & $0.061^{* *}$ & 1.000 \\
\hline
\end{tabular}




\subsection{Associations between industry specialist auditor and KAM quality}

Table 4 presents the regression results for our main hypothesis that explore the association between the industry specialist auditor and KAM disclosure quality. Since HQKAM is a dummy variable and KAM is an ordinal variable, this study processed the logistic regression and ordinal logit regression to explore the research question of this study, respectively.

Column (1) of Table 6 shows that, for the logistic regression, the coefficients of the indicator variables of audited by industrial specialist audit partners (SPE) is significantly positively associated with $H Q K A M$. Similar, the examination of ordinal logit regression, which presented in Column (2) of the table, shows a significant positive association between SPE and KAM. The findings support our hypothesis that compared with the content quality of KAM in an audit report that discussed by non-specialist auditors, the content quality of KAM is higher in the audit report that discussed by specialist auditors. This finding provides evidence supporting prior studies of auditor industry specialist, those suggest industrial specialist auditors to provide higher quality for their audit work and information disclosure.

Table 4: Full Sample Regression Results

\begin{tabular}{|c|c|c|}
\hline & HQKAM & KAM \\
\hline SPE & $0.475^{*}$ & $0.610^{* * * *}$ \\
\hline BIGN & $(0.063)$ & $(0.007)$ \\
\hline & $-0.286^{*}$ & -0.227 \\
\hline CPATEN & $(0.086)$ & $(0.125)$ \\
\hline CPAEXP & -0.006 & -0.024 \\
\hline & $(0.846)$ & $(0.359)$ \\
\hline SIZE & -0.003 & -0.009 \\
\hline & $(0.807)$ & $(0.353)$ \\
\hline CG & -0.007 & 0.015 \\
\hline & $(0.945)$ & $(0.872)$ \\
\hline COMPLEX & 0.037 & 0.023 \\
\hline & $(0.462)$ & $(0.601)$ \\
\hline MB & $-0.006^{*}$ & -0.005 \\
\hline & $(0.099)$ & $(0.121)$ \\
\hline LOSS & $0.071^{*}$ & 0.058 \\
\hline & $(0.089)$ & $(0.118)$ \\
\hline LEV & 0.018 & 0.014 \\
\hline & $(0.899)$ & $(0.906)$ \\
\hline IndustryDummies & $-0.008^{* *}$ & $-0.009^{* * *}$ \\
\hline $\boldsymbol{N}$ & $(0.021)$ & $(0.003)$ \\
\hline Cox \& Snell $\boldsymbol{R}^{\mathbf{2}}$ & Included & Included \\
\hline Nagelkerke $\boldsymbol{R}^{\mathbf{2}}$ & 1554 & 1554 \\
\hline Sig. & 0.038 & 0.042 \\
\hline
\end{tabular}

1. Variable definitions are the same as that in Table 2.

2. $p$-values in parentheses ${ }^{*} \mathrm{p}<0.1,{ }^{* *} \mathrm{p}<0.05,{ }^{* * *} \mathrm{p}<0.01$. 


\subsection{Additional Tests}

\subsubsection{Does auditors' client specific knowledge affect the disclosure quality of KAMs?}

In determine the KAMs, the auditors have to consider the areas that contain a high risk of misrepresentation or material events that involve significant judgments of the management in the financial statements to identify areas of significant risk. In order to make such a judgment, in addition to discuss the significantly impact issues or transactions with the management and governing bodies extensively, the auditors to be familiar with the major economic, accounting, statutory, industrial or other developments that may affect their clients. For newly accept clients, auditors may have less knowledge about their business, and may influence their recognition and disclosure of KAMs as a result. To address these considerations, we provide additional test for companies that change their auditors this year.

Table 5 present the results for considering the possible effects of auditor change on the assocation between auditor industry specialist and content quality of KAM disclosure. Panel A displays sample companies with and without auditor change while Panel B contains only companies those change their auditors in 2016. From Panel A one can find that, the positive association between SPE and KAM is significant only for companies that did not change their auditors for current year, which suggests that auditors' client specific knowledge may affect the quality of KAM disclosure. However, Panel B, which include companies with auditor change only, shows that SPE is the positive association between SPE and KAM is significant only for companies that change both of their auditors at the same time. This study attribute this result to the fact that audit risk is expressively higher for clients that rotated both audit partners at the same time; in order to reduce the risk of possible litigation in the future, the newly appointed audit team will more suspiciously dealing with the KAM communication process with users of audit reports, and provide KAM with higher content quality as a result. 
Table 5: Regression Results Considering the Effects of Auditor Change

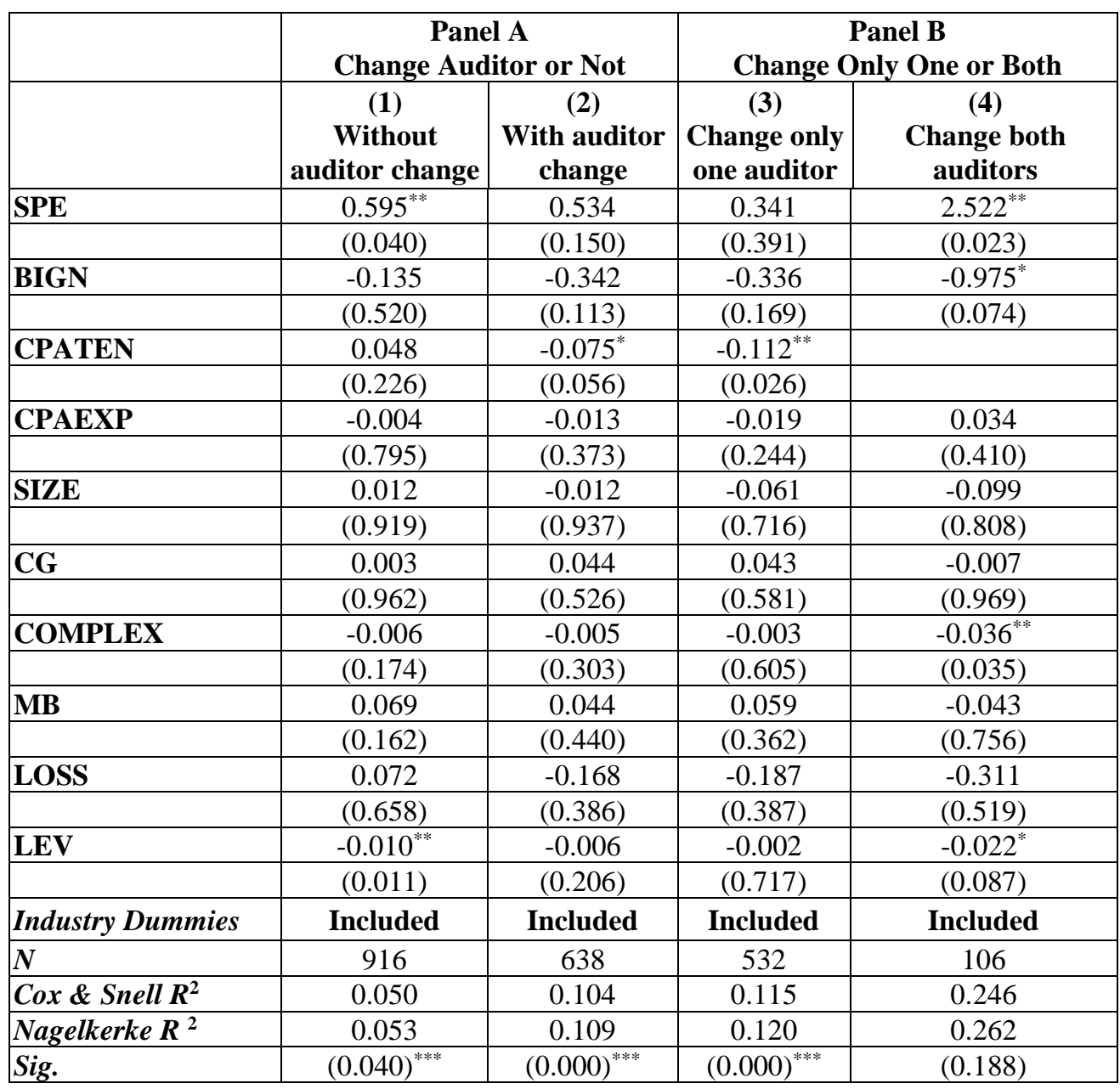

1. Variable definitions are the same as that in Table 2.

2. $p$-values in parentheses ${ }^{*} \mathrm{p}<0.1,{ }^{* *} \mathrm{p}<0.05,{ }^{* * *} \mathrm{p}<0.01$.

\subsection{Impacts of auditor industry specialization of each kind content quality of KAM}

In order to understand the impacts of auditor industrial specialization on the overall KAM content quality, we combined the six KAM content quality indicators into a comprehensive indicator to discuss the research topics in the main analyses. However, the impact of industry specialization on the quality of KAM content may also vary between indicators. Therefore, this study further discusses the impacts of auditor industrial specialization on the quality of six KAM contents in this section. Table 6 presents the logistic results for the six criteria indexes used in this study which examine the association between auditor industrial specialization and whether the matter discussed should be considered as a KAM (KAMI), whether the discussion of KAM provided linkage to a specific level of the account it mentioned (KAM2), whether excessive standardized phraseology is used to discuss KAM 
(KAM3), whether the content of KAM provides the index of KAM-related disclosure in financial reports (KAM4), whether the title of KAM is appropriate $(K A M 5)$, and whether the note of KAM is adequate (KAM6). From Table 6 , one can find that the positive association between SPE and KAM is significant only for column (1), (3), and (6) which suggest that the impact of auditor industry specialization on the content quality of KAM is most significant for correctly identifying KAM issues, avoiding to use excessive standardized phraseology to discuss KAM, and adequately make the note of KAM.

Table 6: Impacts of auditor industry specialization of each kind content quality of KAM

\begin{tabular}{|c|c|c|c|c|c|c|}
\hline & (1) KAM1 & (2)KAM2 & (3)KAM3 & (4)KAM4 & (5)KAM5 & (6)KAM6 \\
\hline \multirow[t]{2}{*}{ SPE } & $0.677^{* * *}$ & 0.050 & $0.477^{* *}$ & 0.196 & $0.739^{* * *}$ & 0.170 \\
\hline & $(0.009)$ & $(0.853)$ & $(0.037)$ & $(0.726)$ & $(0.005)$ & $(0.533)$ \\
\hline \multirow[t]{2}{*}{ BIGN } & 0.136 & $-0.491^{* * *}$ & $0.595^{* *}$ & $-1.504^{* * * *}$ & $-0.800^{* * *}$ & $0.733^{* * *}$ \\
\hline & $(0.436)$ & $(0.003)$ & $(0.012)$ & $(0.005)$ & $(0.000)$ & $(0.000)$ \\
\hline \multirow[t]{2}{*}{ CPATEN } & -0.039 & -0.001 & -0.034 & -0.020 & $-0.061^{* *}$ & $0.072^{* *}$ \\
\hline & $(0.199)$ & $(0.981)$ & $(0.471)$ & $(0.716)$ & $(0.036)$ & (0.019) \\
\hline \multirow[t]{2}{*}{ CPAEXP } & -0.006 & $-0.022^{*}$ & 0.003 & 0.033 & $0.019^{*}$ & $-0.040^{* * *}$ \\
\hline & $(0.625)$ & $(0.052)$ & $(0.884)$ & $(0.136)$ & $(0.090)$ & $(0.001)$ \\
\hline \multirow[t]{2}{*}{ SIZE } & $0.290^{* * * *}$ & -0.010 & 0.159 & 0.150 & -0.158 & $-0.197^{*}$ \\
\hline & $(0.007)$ & $(0.931)$ & $(0.355)$ & $(0.449)$ & $(0.134)$ & $(0.075)$ \\
\hline \multirow[t]{2}{*}{ CG } & -0.038 & $0.134^{* *}$ & -0.106 & 0.051 & 0.043 & -0.043 \\
\hline & $(0.468)$ & $(0.011)$ & $(0.194)$ & $(0.605)$ & $\begin{array}{l}(0.392) \\
\end{array}$ & $(0.418)$ \\
\hline \multirow[t]{2}{*}{ COMPLEX } & -0.005 & 0.003 & -0.002 & $0.021^{* * * *}$ & -0.004 & $-0.011^{* * * *}$ \\
\hline & $(0.164)$ & $(0.487)$ & $(0.731)$ & $(0.006)$ & $(0.292)$ & $(0.007)$ \\
\hline \multirow[t]{2}{*}{ MB } & $0.136^{* * * *}$ & -0.027 & -0.087 & -0.005 & $0.113^{* * * *}$ & -0.052 \\
\hline & $(0.001)$ & $(0.529)$ & $(0.137)$ & $(0.941)$ & $(0.007)$ & $(0.243)$ \\
\hline \multirow[t]{2}{*}{ LOSS } & 0.060 & 0.096 & 0.208 & $-0.459^{*}$ & -0.054 & -0.059 \\
\hline & $(0.673)$ & $(0.504)$ & $(0.374)$ & $(0.057)$ & $\begin{array}{l}(0.700) \\
\end{array}$ & $(0.684)$ \\
\hline \multirow[t]{2}{*}{ LEV } & $-0.008^{* *}$ & $-0.008^{* *}$ & -0.003 & $-0.010^{*}$ & -0.005 & -0.002 \\
\hline & $(0.033)$ & $(0.028)$ & $(0.572)$ & $(0.096)$ & $(0.155)$ & $(0.597)$ \\
\hline $\begin{array}{l}\text { Industry } \\
\text { Dummies }\end{array}$ & Included & Included & Included & Included & Included & Included \\
\hline$N$ & 1554 & 1554 & 1554 & 1554 & 1554 & 1554 \\
\hline Cox \& Snell R & 0.046 & 0.046 & 0.018 & 0.036 & 0.060 & 0.070 \\
\hline Nagelkerke $\mathrm{R}^{2}$ & 0.063 & 0.064 & 0.037 & 0.090 & 0.080 & 0.097 \\
\hline Sig. & $(0.000)^{* * *}$ & $(0.000)^{* * * *}$ & $(0.624)$ & $(0.003)^{* * * *}$ & $(0.000)^{* * * *}$ & $(0.000)^{* * * *}$ \\
\hline
\end{tabular}

1. KAM $1-6$ represent the six KAM content quality related criteria indexes, which KAM 1 is a dummy variable of whether the matter discussed should be considered as a KAM, for that is the matter should be considered as a KAM denote 1, and 0 otherwise; KAM 2 is a dummy variable of whether the discussion of KAM provided linkage to a specific level of the account it mentioned, for that provided linkage to a specific level denote 1, and 0 otherwise; KAM 3 is a dummy variable of whether excessive standardized phraseology is used to discuss KAM, for that excessive standardized phraseology is not used denote 1, and 0 otherwise; KAM 4 is a dummy variable of whether the content of KAM provides the index of KAM-related disclosure in financial reports, for that provides the index of KAM-related disclosure in financial reports denote 1 , and 0 otherwise; KAM 5 is a dummy variable of whether the title of 
KAM is appropriate, for that the title of KAM is appropriate denote 1 , and 0 otherwise; and KAM 5 is a dummy variable of whether the note of KAM is adequate, for that the note of KAM is adequate denote 1 , and 0 otherwise. Definition of other variables are the same as that in Table 2.

2. $p$-values in parentheses ${ }^{*} \mathrm{p}<0.1,{ }^{* *} \mathrm{p}<0.05,{ }^{* * *} \mathrm{p}<0.01$.

\section{Conclusion}

For enhancing the transparency of audit reports, auditing standard development authorities around the world have proposed or approved standards that significantly change an independent auditor's report since 2013. For complying with international trends and enhancing the transparency of audit reports, the ARDF in Taiwan revised the Statements of Auditing Standards in 2015 and released the SAS No. 58, requiring auditors to communicate key matters in an audit and contain these matters in the audit reports. While industry specialist auditors have been demonstrated to possess higher audit quality, no evidence associated with the new audit report has been provided to date. Consequently, the purpose of this study is to explore the association between auditor industry specialization and audit quality from the aspect of communicating matters important to the audit under the new form of audit reports, as denoted by KAM.

To address this question, this study use hand-collected data of the KAM disclosed in the audit reports of Taiwanese listed companies in 2016 and developed a comprehensive indicator which composed by six criteria related to companies' KAM disclosure content. The empirical findings support our hypothesis that compared with the content quality of KAM in an audit report that discussed by nonspecialist auditors, the content quality of KAM is higher in the audit report that discussed by specialist auditors. In addition, the empirical results of considering the effect of auditor change show that auditors' client specific knowledge affect the content quality of KAMs disclosure as well. Furthermore, we further found that the impact of auditor industry specialization on the content quality of KAM is most significant for correctly identifying KAM issues, avoiding to use excessive standardized phraseology to discuss KAM, and adequately make the note of KAM. This study is expected to make the following contributions. First, this study use hand-collected data from KAM in Taiwan to provide empirical evidence regarding the consequence of the revolution in audit reporting since there is still rare related empirical evidence. Next, distinct with Lennox et al. (2015), who provides evidence about the users' response of audit reports, this study is expected to provide evidence about the response of audit report providers for the new audit standard. This is our second contribution.

Finally, while industry specialist auditors typically demonstrate higher audit quality, no evidence associated with the new audit report has been provided to date. This study provide evidence of the impact of auditor industry specialization on audit quality under the new audit regulation region, and this is our third contribution. 


\section{References}

[1] Accounting Research and Development Foundation (ARDF). (2016). "Communicating Key Audit Matters in the Independent Auditor's Report". Statements of Auditing Standards (SAS) 58. Taipei, R.O.C.: ARDF.

[2] Backof, A., Bowlin, K. and Goodson, B. (2017). The impact of proposed changes to the content of the audit report on jurors' assessments of auditor negligence. Working paper. University of Virginia, University of Mississippi and University of Cincinnati.

[3] Balsam, S., Krishnan, J. and Yang, J.S. (2003). Auditor industry specialization and earnings quality. Auditing: A Journal of Practice \& Theory 22: 71-97.

[4] Becker, C. L., DeFond, M.L., Jiambalvo, J. and K. Subreamanyam. (1998). The effect of audit quality on earnings management. Contemporary Accounting Research 15: 1-24.

[5] Bédard, J., Coram, P., Espahbodi, R. and Mock, T. J. (2016). Does recent academic research support changes to audit reporting standards? Accounting Horizons 30(2): 255-275.

[6] Behn, B. K., Choi, J. and Kang, T. (2008). Audit quality and properties of analyst earnings forecasts. Accounting Review 83(2): 327-349.

[7] Boolaky, P. K. and Quick, R. (2016). Bank directors' perceptions of expanded auditor's reports. International Journal of Auditing 20(2): 158-174.

[8] Brasel, K., Doxey, M. M., Grenier, J. H. and Reffett, A. (2016). Risk disclosure preceding negative outcomes: The effects of reporting critical audit matters on judgments of auditor liability. Accounting Review 91(5): 1345-1362.

[9] Bruynseels, L., Knechel, W. R. and Willekens, M. (2011).

Auditor differentiation, mitigating management actions, and audit-reporting accuracy for distressed firms. Auditing: A Journal of Practice \& Theory 30(1): $1-20$.

[10] Carcello, J. V., and Nagy, A. L. (2004). Audit firm tenure and fraudulent financial reporting. Auditing: A Journal of Practice \& Theory 23(2): 55-69.

[11] Carey, P. and Simnett, R. (2006). Audit partner tenure and audit quality. The Accounting Review 81(3): 653-676.

[12] Cenker, W. J. and Nagy, A. (2008). Auditor resignations and auditor industry specialization. Accounting Horizons 22 (3): 279-295.

[13] Chen, C. H. (2017). Analysis on the status of key audit matters for new audit report implementation in the first year. Master's dissertation. National Taipei University, Taiwan, R.O.C.

[14] Chin, C. and Chi, H. Y. (2009). Reducing restatements with increased industry expertise. Contemporary Accounting Research 26(3): 729-765.

[15] Christensen, B. E., Glover, S. M. and Wolfe, C. J. (2014). Do critical audit matter paragraphs in the audit report change nonprofessional investors' decision to Invest? Auditing: A Journal of Practice and Theory 33(4): 71-93.

[16] Craswell, A. T., Stokes, D. J. and Laughton, J. (2002). Auditor independence and fee dependence. Journal of Accounting and Economics 33(3): 72-87. 
[17] Craswell, A. T., Francis, J. R and Taylor, S. L. (1995). Auditor brand name reputations and industry specializations. Journal of Accounting and Economics 20(3): 297-322.

[18] DeAngelo, L. E. (1981). Auditor size and audit quality. Journal of Accounting and Economics 3(3): 183-199

[19] DeFond, M. L., Raghunandan, K. and Subramanyam, K. R. (2002). Do nonaudit service fees impair auditor independence? Evidence from goingconcern audit opinions. Journal of Accounting Research 40 (4): 1247-1274.

[20] Emby, C. and M. Favere-Marchesi. (2010). Review partners and engagement partners: The interaction process in engagement quality review. Auditing: A Journal of Practice \& Theory 29 (2): 21-32.

[21] Financial Reporting Council (FRC). (2014). International Standard on Auditing (UK and Ireland) 700. The independent auditor's report on financial statements (September). London, U.K.: FRC.

[22] Francis, J., Maydew, E. and Sparks, H. (1999). The role of Big 6 auditors in the credible reporting of accruals. Auditing: A Journal of Practice \& Theory 18 (Fall): 17-34.

[23] Francis, J., LaFond, R., Olsson, P. and Schipper, K. (2005), The market pricing of accruals quality, Journal of Accounting and Economics, 39, issue 2, p. 295327.

[24] Geiger, M. A. and Raghunandan, K. (2002). Auditor tenure and audit reporting failures. Auditing: A Journal of Practice \& Theory 21(1): 67-78.

[25] Ghosh, A., and Moon, D. (2005). Auditor tenure and perceptions of audit quality. Accounting Review 80: 585-612.

[26] Gimbar, C., Hansen, B. and Ozlanski, M. E. (2016). The effects of critical audit matter paragraphs and accounting standard precision on auditor liability. Accounting Review 91(6): 1629-1646.

[27] Gul, F. A., Fung, S. Y. K. and Jaggi, B. (2009). Earnings quality: Some evidence on the role of auditor tenure and auditors' industry expertise. Journal of Accounting and Economics 47: 265-287.

[28] Gutierrez, E. F., Minutti-Meza, M., Tatum, K. W. and Vulcheva, M. (2018). Consequences of changing the auditor's report: Evidence from the U.K. Working Paper.

[29] International Auditing and Assurance Standards Board (IAASB). (2011). Consultation Paper: Enhancing the Value of Auditor Reporting: Exploring Options for Change. New York, NY: International Federation of Accountants.

[30] International Auditing and Assurance Standards Board (IAASB). (2012a). Invitation to Comment: Improving the Auditor's Report. New York, NY: International Federation of Accountants.

[31] International Auditing and Assurance Standards Board (IAASB). (2012b). Auditor Reporting: Summary of Responses Relating to Going Concern (GC). IAASB Main Agenda Item 6-B of the December 2012 IAASB Meeting.

[32] International Auditing and Assurance Standards Board (IAASB). (2013). Exposure Draft. Reporting on Audited Financial Statements: Proposed New 
and Revised. International Standards on Auditing (ISAS). New York, NY: International Federation of Accountants.

[33] International Auditing and Assurance Standards Board (IAASB). (2015a). Forming an Opinion and Reporting on Financial Statements. International Standard on Auditing (ISA) 700. New York, NY: International Federation of Accountants.

[34] International Auditing and Assurance Standards Board (IAASB). (2015b). Communications Key Audit Matters in the Independent Auditor's Report. International Standard on Auditing (ISA) 701. New York, NY: International Federation of Accountants.

[35] International Auditing and Assurance Standards Board (IAASB). (2015c). At a Glance: New and Revised Auditor Reporting Standards and Related Conforming Amendments. New York, NY: International Federation of Accountants.

[36] Johnson, V. E., Khurana, I. K. and Reynolds, J. K. (2002). Audit-firm tenure and the quality of financial reports. Contemporary Accounting Research 19(4): 637-660.

[37] Wu, J., Habib, A., Weil, S. (2012). AUDIT COMMITTEE EFFECTIVENESS: A SYNTHESIS OF THE AUDIT COMMITTEE LITERATURE. Corporate Board: Role, Duties \& Composition, 8(1).

[38] Krishnan, J. and Press, E. (2003). The north American industry classification system and its implications for accounting research. Contemporary Accounting Research 20(4): 685-717.

[39] Lennox, C., Schmidt, J. and Thompson, A. (2015). Is the expanded model of audit reporting informative to investors? Evidence from the UK. Working Paper.

[40] Lim, C.Y. and Tan, H.T. (2010). Does auditor tenure improve audit quality? Moderating effects of industry specialization and fee dependence. Contemporary Accounting Research 27(3): 923-957.

[41] Lim, C.Y. and Tan, H.T. (2008). Non-Audit Service Fees and Audit Quality: The Impact of Auditor Specialization. Journal of Accounting Research. 46. 199-246. 10.2139/ssrn.1003331.

[42] Liu, L., Xie, X., Chang, Y. and Forgione, D. A. (2017). New clients, audit quality, and audit partner industry expertise: Evidence from Taiwan. International Journal of Auditing 21(3): 288-303.

[43] Mansi, S., Maxwell, W. and Miller, D. (2004). Does auditor quality and tenure matter to investors: Evidence from the bond market. Journal of Accounting Research 42, 755-793.

[44] Mascarenhas, D., Cahan, S. F. and Naiker, V. (2010). The effect of audit specialists on the informativeness of discretionary accruals. Journal of Accounting, Auditing and Finance 25(1): 53 - 84.

[45] Myers, J. N., Myers, L. A. and Omer, T. C. (2003). Exploring the term of the auditor-client relationship and the quality of earnings: A case for mandatory auditor rotation? Accounting Review 78: 779-799. 
[46] Payne, J. L. (2008). The influence of audit firm specialization on analysts' forecast errors. Auditing: A Journal of Practice \& Theory 27(2): 109-136.

[47] Public Company Accounting Oversight Board (PCAOB), (2011). Concept Release on Auditor Independence and Audit Firm Rotation. PCAOB Release No. 2011-006, August 16, 2011. Washington: PCAOB.

[48] Public Company Accounting Oversight Board (PCAOB). (2013a). The Auditor's Report of an Audit of Financial Statements When the Auditor Expresses an Unqualified Opinion; The Auditor's Responsibilities Regarding Other Information in Certain Documents Containing Audited Financial Statements and the Related Auditor's Report. Release No. 2013-005. New York, NY: PCAOB.

[49] Public Company Accounting Oversight Board (PCAOB). (2013b). Improving the Transparency of Audits: Proposed Amendments to PCAOB Auditing Standards to Provide Disclosure in the Auditor's Report of Certain Participants in the Audit. Release No. 2013-009. New York, NY: PCAOB.

[50] Public Company Accounting Oversight Board (PCAOB). (2013b). Proposed Auditing Standard on the Auditor's Report on an Audit of Financial Statements when the Auditor Expresses an Unqualified Opinion. Release No. 2013-009. New York, NY: PCAOB.

[51] Public Company Accounting Oversight Board (PCAOB). (2015). Supplemental Request for Comment: Rules to Require Disclosure of Certain Audit Participants on a New Form. Release No. 2015-004. New York, NY: PCAOB.

[52] Public Company Accounting Oversight Board (PCAOB). (2016). Proposed Auditing Standard on the Auditor's Report on an Audit of Financial Statements when the Auditor Expresses an Unqualified Opinion. Release No. 2016-003. New York, NY: PCAOB.

[53] Public Company Accounting Oversight Board (PCAOB). (2017). PCAOB Adopts New Standard to Enhance the Relevance and Usefulness of the Auditor's Report with Additional Information for Investors. Release 2017. New York, NY: PCAOB.

[54] Reichelt, K.J. and Wang, D. (2010). National and office-specific measures of auditor industry expertise and effects on audit quality. Journal of Accounting Research 48: 647-686.

[55] Reynolds, J. K. and Francis, J. (2000). Does size matter? The influence of large clients on office-level auditor reporting decisions. Journal of Accounting and Economic 30: 375-400.

[56] Robinson, D. (2008). Auditor independence and auditor-provided tax service: Evidence from Going-concern audit opinions prior to bankruptcy filings. Auditing: A Journal of Practice \& Theory 27(2): 31-54.

[57] Romanus, R. N., Maher, J. J. and Fleming, D. M. (2008). Auditor industry specialization, auditor changes, and accounting restatements. Accounting Horizons 22(4): 389-413. 
[58] Rose-Green, E., Huang, H. W. and Lee, C. C. (2011). The association between auditor industry specialization and firms' disclosure of internal control weaknesses. International Journal of Auditing 15(2): 204-216.

[59] Schauer, P. (2002). "The Effects of Industry Specialization on Audit Quality: An Examination using Bid-Ask Spreads", Journal of Accounting and Finance Research, Vol 10 No. 1, pp.76-86.

[60] Simnett, R. and Huggins, A. (2014). Enhancing the auditor's report: To what extent is there support for the IAASB's proposed changes? Accounting Horizons 28(4): 719-747.

[61] Sirois, L. P., Be'dard, J. and Bera, P. (2018). The informational value of key audit matters in the auditor's report: Evidence from an eye-tracking study. Accounting Horizons 32(2): 141-162.

[62] Sirois, L.P., Bédard, J. and Palash, B. (2018). The Informational Value of Key Audit Matters in the Auditor's Report: Evidence from an Eye-Tracking Study. Accounting Horizons. 32. 10.2308/acch-52047.

[63] Sultana, N., Singh, H. and Van der Zahn, J. M. (2015). Audit committee characteristics and audit report lag. International Journal of Auditing 19(2): $72-87$.

[64] Vanstraelen, A., Schelleman, C., Meuwissen, R. and Hofmann, I. (2012). The audit reporting debate: Seemingly intractable problems and feasible solutions. European Accounting Review 21(2): 193-215.

[65] Zerni, M.P. (2011). Audit Partner Specialization and Audit Fees: Some Evidence from Sweden. Financial Accounting eJournal. 